\title{
BOARD DIVERSITY AND DIVIDEND PAYOUT RATIO: EVIDENCE FROM FAMILY FIRMS IN INDONESIA
}

\author{
Rahmat Setiawan* \& Annisa Paramaswary Aslam \\ Faculty of Economics and Business, Universitas Airlangga
}

\begin{abstract}
This study investigates the impact of Board of Commissioners (BoC) diversities on dividend payments in the listed family firms in Indonesia. This study uses diversity for gender, nationality and tenure to describe the board of commissioner diversities. Using a data set of listed family firms in Indonesia Stock Exchange over the period 2012-2016, we find evidence indicating that board gender diversity is positively related to dividend payment. Secondly, we find evidence that board tenure diversity is positively related to dividend payments. However, the board nationality diversity does not remain significant on dividend payments.
\end{abstract}

Keywords: Board Diversity, Dividend, Family Firms

* Corresponding authors: rahmatsetiawan@feb.unair.ac.id /

annisa.paramaswary.aslam-2016@feb.unair.ac.id

DOI: $10.24252 /$ minds.v5i2.6232

ISSN-E: 2597-6990 


\section{INTRODUCTION}

Family businesses are believed to be the engine of growth for many countries. More than 95 percent of the world's businesses are family owned, generating millions of employees and playing a vital role in the economy. In the Asia Pacific, the top 85 family firms have more than 3 million employees and give 4.3 percent of the region's gross domestic product (Global Family Business Index, 2015). Then, family firms in Indonesia contribute around $40 \%$ of market capitalization in Indonesia and have the largest in various major industries including property (91\%), agriculture (74\%), energy (65\%) and consumer goods (45\%) (Boston Consulting Group Report, 2016). However, family firms are characterized by the absence of effective external governance mechanisms and conflicts between majority principals and minority principals (Morck et al., 2005). This conflict has called as the minority-majority conflict, which this conflict involves the majority and minority principals in a firm (Dharwadkar et al., 2000).

Young et al., (2008) showed that developing countries, including Indonesia, tend to have agency conflicts between majority shareholders and minority shareholders. The conflicts are due to the fact that companies in Indonesia are generally dominated by family-owned companies which usually have a strong relationship to company managers (Claessens et al., 2000; Chen, 2001; La Porta et al., 1999). Family-owned companies can take over company resources and appoint non-qualified families in management firm (Carney, 1998; Claessens et al., 2000). Agency problems that occur in family companies are due to shareholders who can control the company's management. So, the majority shareholders will take action that are beneficial for them and can harm the minority shareholders (Young et al,2008).

Schulze et al., (2001) found that family firms generally have agency conflicts that are more difficult to resolve because the relationship between the owner and management is based on emotions, sentiments, and informal relationships. This relationship makes management tends to take actions that make the benefits for controlling shareholders and will make the company becomes ineffective (Young et al, 2008). Therefore, the implementation of Good Corporate Governance (GCG) is playing a vital role in a company. The GCG aims to maintain the efficiency of the company through the principles of transparency, responsibility, accountability, independency, and fairness. It also aims to protect the rights and obligations of shareholders.

Companies in Indonesia are one of the countries that adopt the two-tier system, where the board of commissioners (BoC) and the board of directors (BoD) are separated. BoD is responsible for carrying out the management of the company for the benefit of the company and in accordance with the objectives and purposes of the company (Law of The Republic of Indonesia Number 40 of 2007 concerning limited liability companies). On the contrary, the duties of BoC are to supervise the management policies, both regarding the Company and the Company's business and advise the Directors (Article 108 of Law No. 40 of 2007 
concerning Limited Liability Companies). The board of commissioners is appointed by the shareholders through the GMS.

The duties and functions of BoC are to control management well and to be fair to minority and majority shareholders. The presence of the board of commissioners aims to make the company have a good corporate governance function and the company's agency conflict can be reduced.

Agency problems will cause agency costs. There are several ways to reduce agency costs, one of which is to pay dividends and increase funding with debt (Megginson, 1997). Furthermore, Megginson (1997) shows that dividend distribution and debt payment can be used as a management bonding mechanism. Bonding management is a form of control mechanism through a manager's policy to be able to secure shareholders. Bonding aims to equate the interests of management through programs that bind management's personal wealth into the wealth of the company (Megginson, 1997).

Paying higher dividends to shareholders will reduce the free cash flow available to company management thus reducing the level of agency problems (Firth, Gao, Shen, \& Zhang, 2016; Ben-Nasr, 2015). The company's board of commissioners can influence company management by asking management to pay higher dividends when management tends to want to maintain excess cash. One way that can be done is to have a board of commissioners who have a background that can affect management's overall decisions, including those relating to dividends (Saeed and Sameer, 2017).

The diversity of the BoC can be seen in terms of gender, nationality and tenure of the board of commissioners. For example, women contribute to improve the quality of corporate governance by providing different perspectives in discussion and making the board more attractive (Chen et al., 2014). Byoun (2016) found that US companies with gender diversity boards tend to increase the propensity to pay dividend.

In addition, the existence of foreign citizens can take a variety of opinions and professional experience and different thoughts on the board of commissioners (Ararat et al., 2010). Hamzah and Zulkafli (2014) show that the diversity of foreign commissioners is positively related to dividend payout. The study shows that having foreign commissioners on the boardroom will bring benefits to shareholders because the board will become more independent and monitoring can run well, so the level of expropriation in the company can be reduced.

The long term of the board of commissioners makes commissioners grow mature and prudent in the decision-making in the company. Hamzah and Zulkafli (2014) explain that long board tenure has a negative relationship with the corporate expropriation in Malaysian public companies. Therefore, the company needs to follow the recommendations of The Malaysian Corporate Governance Code, which suggests the commissioner tenure should be lower or the same as nine years. It aims to prevent a close relationship between management and commissioners. Presence of diverse commissioners in emerging countries is important (Saeed and Sameer, 2017; Bathala \& Rao, 1995; Faccio et al., 2001). 


\section{LITERATURE REVIEW}

\section{Agency Theory}

In emerging economies, like Indonesia, laws and regulations regarding accounting requirements, information disclosure, securities trading, and their enforcement are inefficient (Young et al, 2008). Therefore, standard of corporate governance system in emerging economies tends to relatively small (Peng, 2004; Peng et al., 2003) and relational ties, business groups, family connections, and government contacts, playing vital role in corporate governance (Peng and Heath, 1996; Yeung, 2006).

Institutional environments in emerging economies are weak, and the founding family still control their firms. Firms tried to appear from founder control to professional management, but the founder still keep to control the firms (Liu et al., 2006; Young et al., 2004). Therefore, family firms may do the expropriation of non-family minority shareholders (Bloom and Van Reenen, 2006). Family owners may do the expropriation and add nor competent family members to management (Carney, 1998; Claessens et al., 2000). Shleifer and Vishny (1997) argue that this strategy can make the majority shareholders to do easily the expropriation. So, corporate should have BoC that can protect the minority shareholder and reduce the expropriation from management or controlling shareholder.

Gender Diversity

Commissioner board with high gender diversity is believed that have a more effective monitoring ability to the manager in order to protect the shareholders interest (Adams and Ferreira, 2009). In addition, a gender diverse board have greater monitoring than non-diverse board, because diverse board tend to have various ideas and active suggestions in evaluating management decisions (Chen et al., 2014). Female commissioners are supposed to be good monitors to protect the shareholders right. The presence of female commissioners on the commissioner board enhanced the board more independent (Fondas and Sassalos, 2000). In addition, women will enhance the quality of governance in the boardroom by giving different perspective and make a board more interactive and increase the board efficiency (Sing et al., 2008; Ruigrok et al., 2007). Therefore, female commissioners would give advantages to the shareholder and increase the monitoring effectively in the board (Hamzah dan Zulkafli, 2014).

Gender Diversity $=\left(\frac{\text { The number of women commissioners on the board }}{\text { The umber of all board members commissioners }}\right) \times 100 \ldots . . .2 .1$

\section{Nationality Diversity}

Denis and McConnel (2003) explain that corporate governance aims to maximize the firm value. Therefore, every action and decision are expected to give advantages to all principals of the company. Shleifer and Vishny (1997) argue that good corporate governance will make the management to give the return on shareholder's investments, and the $\mathrm{BoC}$ roles are to protect the shareholders' interest. It is consistent with Claessens (2006) view that the BoC take the important role in corporate governance. 
Nationality diversity on BoC will make a better decision and strategy for company and will increase the monitoring to avoid the expropriation by management of the company. When the monitoring is success, the expropriation will reduce in company. Having foreign board in board room increased the monitoring function. Then, the foreign board presence made the boardroom more independent. It caused expropriation has reduced and the power of existing board members has resisted (Choi et al., 2007), foreign board bring new idea, views, experiences and perspectives (Ararat et al., 2010).

Nationality Diversity $=\left(\frac{\text { The number of foreign commissioners on the board }}{\text { The number of all board members commissioners }}\right) \times 100 \ldots \ldots . . . .2 .2$

\section{Tenure Diversity}

The other factor that determines the commissioner quality is board tenure. Making commissioners to retire quickly, will leads to a waste of talent and experience (Vance, 1983). With their vast experience, it can enhance the effectiveness of the monitoring in the firm (Liu \& Sun, 2005). The NACD (1996) recommends the tenure of the board have to a maximum of 10 to 15 years. It aims to get the new ideas and critical thinking for management. Similarly, Hamzah and Zulkafli (2014) find that longer board tenure indicate a higher corporate expropriation. This cause board members with longer tenure have strong relationship with the management that bring the expropriations and make the monitoring be less effective.

Therefore, the firms need to have a right composition for the tenure of BoC. It aims that the board of commissioners can be critical in providing appropriate advice for the management of the company and conducting good supervision (Vafeas, 2003). When monitoring in family firms goes well, the expropriation at the firms will decrease. Expropriation is the process of using controls to maximize the insider welfare of a company. There are several policies that can lead to expropriation such as a declining dividend policy that is not even distributed. So, it can be concluded if monitoring in a company is going well, then expropriation will decrease and dividends distributed to shareholders will be higher.

Tenure Diversity $=$

$\left(\frac{\text { The number of commissioners whose tenure is equal or greater than to } 9 \text { years }}{\text { The number of all board members commissioners }}\right) \times 10 \ldots . . .2 .3$

\section{Dividend Payout Ratio}

The dividends paid by companies divided by the profits available to shareholders are known as the dividend payout ratio (DPR) (Hartono, 1998). Ang (1997) states that the greater the dividends distributed, the greater the dividend payout ratio will make investors interested. However, the dividend payout ratio will weaken the company's internal financial because it minimizes retained earnings. Therefore, managers must see clearly whether the decision will have an effect on shareholders. Almost all companies have an awareness of the target level of dividend payments in the long run. If management tries to follow targets every year, the level of dividends will be fluctuating or 
uncertain. Management tries to flatten dividends by changing dividends every year. Management also has an expected return in the future, which aims to regulate its long-term targets. Increased dividends are a sign of management being optimistic about the company's prospects going forward.

Dividend Payout Ratio $=\frac{\text { Dividend per share }}{\text { Earning per share }}$

The Relationship between Gender Diverse Board on Dividend Payout Ratio

Gender diverse board have greater monitoring than no diverse board, because they have various thinking and active oversights in evaluating management decisions (Chen et al., 2014). Female commissioners are supposed to be a good monitor that aims to guide the shareholders right. Empirical evidences show that gender diverse boards positively related to dividend payout. For example, Van Pelt (2013) find that gender diverse board and dividend payout ratio are significantly positive. Jurkus et al., (2011) show a greater percentage of female commissioners in US firms indicate a smaller agency cost and higher dividends. Byoun (2016) shows that firms with high gender diversities in commissioner board tend to pay higher dividends than firms with low gender diversities in commissioner board.

\section{The Relationship between Nationality Diverse Board on Dividend Payout Ratio}

Nationality diversity on BoC will make a better decision and strategy for company and will increase the monitoring to avoid the expropriation by management of the company. When the monitoring is success, the expropriation will reduce in company. The foreign commissioner in board of commissioners increased the monitoring function because the board becomes more independent. It caused a decreasing in expropriation (Choi et al., 2007). Foreign board could be a good corporate governance mechanism. A foreign commissioner brings new idea, experiences and perspectives (Ararat et al., 2010).

\section{The Relationship between Tenure Diverse Board on Dividend Payout Ratio}

Board members will get mature when tenure on the board is long. When the boardroom grows mature, it will affect in the decision making. Buchanan (1974) suggests that long tenure increases organizational promise and willingness to expend effort toward company goals. But, The NACD (1996) recommends the tenure of the board have to a maximum of 10 to 15 years. It aims to get the new ideas and critical thinking for management. Similarly, Hamzah and Zulkafli (2014) find that longer board tenure may indicate a higher corporate expropriation. This causes board members with greater tenure have strong relationship with the management that bring the expropriations and make the monitoring be less effective.

Therefore, the company needs to have a right composition for the tenure of BoC. It aims that the board of commissioners can be critical in providing appropriate advice for the management of the company and conducting good supervision (Vafeas, 2003). When monitoring in family firms goes well, the 
expropriation at the firms will decrease. Expropriation is the process of using controls to maximize the insider welfare of a company. There are several policies that can lead to expropriation such as a declining dividend policy that is not even distributed. So, it can be concluded if monitoring in a company is going well, then expropriation will decrease and dividends distributed to shareholders will be higher.

From the description above, a conceptual framework can be developed in Figure 1.

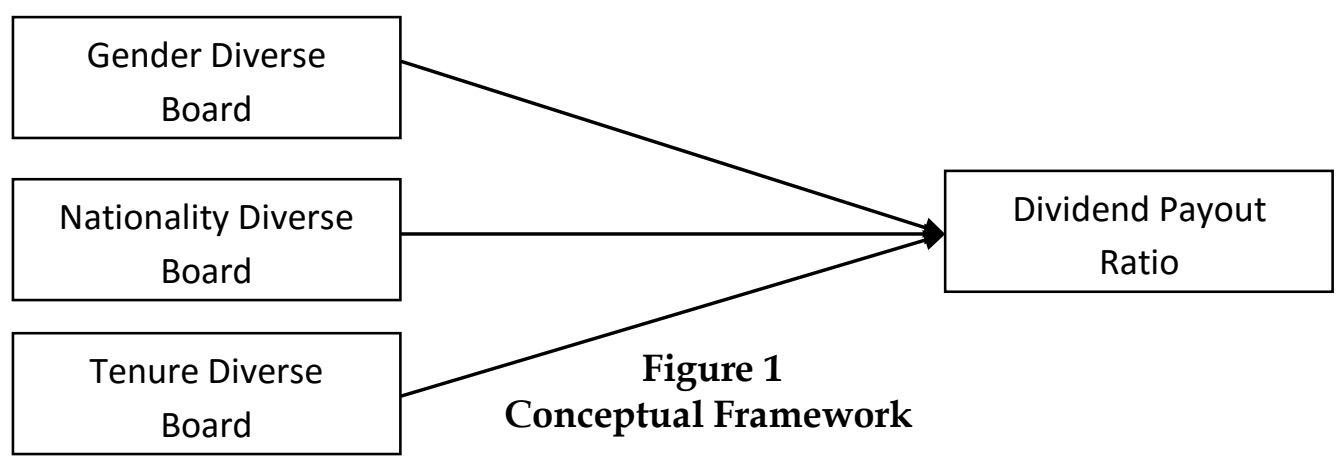

From the picture above, the hypotheses that will be tested in this study can be formulated as follows :

1. Board gender diversity is positively related to dividend payouts in family firms.

2. Board nationality diversity is positively related to dividend payouts in family firms.

3. Board tenure diversity is positively related to dividend payouts in family firms.

\section{METHODOLOGY}

This study used a sample of family firms listed on Indonesia stock Exchange and consistently published financial statements in Rupiah during period 2012-2016. We got final sample of 51 firms for gender variable and 54 family firms for nationality and tenure variable. This study uses three models because researchers have tried to use one model, but the diversity of gender, nationality and tenure on the board of commissioners in Indonesia is still rare in some Non-Financial firms. So, the researchers used three models that aims to avoid the biased on this research. The OLS regression model will be used to test all hypotheses in this research, the model is shown as below :

Model 1 :

To find out the effect of gender diversity on dividend payout ratio with firm size and board size control variables, it is necessary to build a regression equation model as follows:

$$
D I V_{i t}=\beta_{0}+\beta_{1} \text { GENCOM }_{i t}+\beta_{2} \text { FIRSIZ }_{i t}+\beta_{3} \text { BOASIZ }_{i t}+\varepsilon_{i t}
$$


Model 2 :

To find out the effect of nationality diversity on dividend payout ratio with firm size and board size control variables, it is necessary to build a regression equation model as follows:

$$
D I V_{i t}=\beta_{0}+\beta_{1} \text { NATCOM }_{i t}+\beta_{2} \text { FIRSIZ }_{i t}+\beta_{3} \text { BOASIZ }_{i t}+\varepsilon_{i t}
$$

Model 3:

To find out the effect of tenure diversity on dividend payout ratio with firm size and board size control variables, it is necessary to build a regression equation model as follows:

$$
D I V_{i t}=\beta_{0}+\beta_{1} \text { TENCOM }_{i t}+\beta_{2} \text { FIRSIZ }_{i t}+\beta_{3} \text { BOASIZ }_{i t}+\varepsilon_{i t}
$$

Where :

$\begin{array}{ll}\text { DIV } & =\text { Dividend Payout Ratio } \\ \text { GENCOM } & =\text { Gender Commissioners } \\ \text { NATCOM } & =\text { Nationality Commissioners } \\ \text { TENCOM } & =\text { Tenure Commissioners } \\ \text { FIRSIZ } & =\text { Firm Size } \\ \text { BOASIZ } & =\text { Board Size } \\ \varepsilon & =\text { Error }\end{array}$

RESULT AND DISCUSSION

\section{Descriptive statistics}

Table 1

Descriptive Statistics

\begin{tabular}{|l|l|l|l|l|l|}
\hline \multicolumn{1}{|c|}{ GENDER } & $\mathrm{N}$ & Min & Max & Mean & Std Dev \\
\hline DIV & 186 & 0,0000 & 0,777 & 0,0928 & 0,1617 \\
GENCOM & 186 & 0,0000 & 0,6667 & 0,1402 & 0,1712 \\
FIRSIZ & 186 & 19,812 & 31,782 & 27,943 & 2,0723 \\
BOASIZ & 186 & 0,6931 & 2,1972 & 1,3099 & 0,3573 \\
& & & & & \\
\hline NATIONALITY & $\mathrm{N}$ & Min & Max & Mean & Std Dev \\
\hline DIV & 212 & 0,0000 & 0,5928 & 0,1454 & 0,1587 \\
NATKOM & 212 & 0,0000 & 1,0000 & 0,0732 & 0,1805 \\
FIRSIZ & 212 & 19,812 & 32,151 & 28,247 & 2,1247 \\
BOASIZ & 212 & 0,6931 & 2,1972 & 1,3629 & 0,3655 \\
& & & & & \\
\hline \multicolumn{1}{|c|}{ TENURE } & $\mathrm{N}$ & Min & Max & Mean & Std Dev \\
\hline DIV & 257 & 0,0000 & 0,7774 & 0,1443 & 0,1728 \\
TENKOM & 257 & 0,0000 & 1,0000 & 0,4592 & 0,3147 \\
FIRSIZ & 257 & 19,812 & 32,151 & 28,126 & 1,9792 \\
BOASIZ & 257 & 0,6931 & 2,1972 & 1,3181 & 0,3499 \\
& & & & & \\
\hline
\end{tabular}

Table 1 presented the descriptive statistics for all variables 1 . The observations of this research are 51 public family firms in Indonesia. The 
maximum and mean of dividend payout ratio value are 0,092 and 0,777. In gender observations, some family firms have zero woman commissioners, while a family firm has the maximum of 0,6667 woman sit in the board of commissioners. On other hand, for nationality diverse board observation used 54 listed family companies in Indonesia. The mean and maximum of dividend payout ratio are 0,145 and 0,5928 . In observations of nationality diversity, some family firms have zero foreign commissioners. On another hand, some family firms have full of foreigners commissioners sit in the boardroom. And for board tenure diversity observations used 54 listed family companies in Indonesia. The mean and maximum of dividend payout ratio are 0,144 and 0,7774 . In tenure observations, some family firms in Indonesia have zero commissioners with tenure minimum of 9 years while some family firms have all commissioners with tenure 9 years or more than 9 years.

\section{Hypotheses Test}

Table 2 shows the regression result of the gender diversity of commissioner boards and dividend payout ratio. The board gender diversity has a positive relationship with dividend payout ratio. If gender diversity is effective in monitoring and resolve the shareholder-manager conflict of interests, then it tend to disciplines management for influencing payout policy (McGuinness et al., 2015). Previous study shows that female commissioners are expected to be good monitors that further strengthen the shareholder rights

Table 2

The Result of Gender Regression Model

\begin{tabular}{|c|c|c|c|c|c|c|c|}
\hline \multirow[b]{2}{*}{ Model 1} & & & \multicolumn{2}{|c|}{$\begin{array}{l}\text { Unstandardized } \\
\text { Coefficients }\end{array}$} & \multirow{2}{*}{$\begin{array}{c}\text { Standardized } \\
\text { Coefficients } \\
\text { Beta }\end{array}$} & \multirow[b]{2}{*}{$\mathrm{T}$} & \multirow[b]{2}{*}{ Sig. } \\
\hline & & & B & Std. Error & & & \\
\hline \multicolumn{3}{|c|}{ (Constant) } & $-0,786$ & 0,148 & & $-5,328$ & $0,000^{*}$ \\
\hline \multicolumn{3}{|c|}{ GENCOM } & 0,133 & 0,063 & 0,141 & 2,102 & $0,037^{*}$ \\
\hline \multicolumn{3}{|c|}{ FIRSIZ } & 0,026 & 0,005 & 0,332 & 4,935 & 0,000 * \\
\hline \multicolumn{3}{|c|}{ BOASIZ } & 0,105 & 0,030 & 0,231 & 3,514 & $0,001^{*}$ \\
\hline $\mathrm{R}$ & & 0,472 & & & & & \\
\hline $\mathrm{R}^{2}$ & & 0,223 & & & & & \\
\hline \multicolumn{8}{|c|}{ Std. Error $=0,1437$} \\
\hline $\mathrm{F}$ & & 17,421 & & & & & \\
\hline Sig & & 0,000 & & & & & \\
\hline
\end{tabular}

Result reported in Table 3 indicates that insignificant relationship between nationality diversity on $\mathrm{BoC}$ and dividend payout ratio. As evidenced, our 
study found that there are rarely a foreign commissioner sits on the board of family firms in Indonesia. The findings could also be explained by the lack of talented foreign commissioner in certain fields.

Table 3

The Result of Nationality Regression Model

\begin{tabular}{|c|c|c|c|c|c|c|c|}
\hline \multirow[b]{2}{*}{ Model } & & & \multicolumn{2}{|c|}{$\begin{array}{l}\text { Unstandardized } \\
\text { Coefficients }\end{array}$} & \multirow{2}{*}{$\begin{array}{c}\text { Standardized } \\
\text { Coefficients } \\
\text { Beta }\end{array}$} & \multirow[b]{2}{*}{$\mathrm{T}$} & \multirow[b]{2}{*}{ Sig. } \\
\hline & & & B & Std. Error & & & \\
\hline \multicolumn{3}{|c|}{ (Constant) } & $-0,782$ & 0,132 & & $-5,918$ & $0,000^{*}$ \\
\hline \multicolumn{3}{|c|}{ NATCOM } & 0,032 & 0,056 & 0,037 & 0,576 & 0,565 \\
\hline \multicolumn{3}{|c|}{ FIRSIZ } & 0,030 & 0,005 & 0,389 & 6,278 & $0,000^{*}$ \\
\hline \multicolumn{3}{|c|}{ BOASIZ } & 0,060 & 0,028 & 0,139 & 2,164 & $0,032^{*}$ \\
\hline $\mathrm{R}$ & & 0,460 & & & & & \\
\hline $\mathrm{R}^{2}$ & & 0,211 & & & & & \\
\hline \multicolumn{8}{|c|}{ Std. Error $=0,1419$} \\
\hline $\mathrm{F}$ & & 18,578 & & & & & \\
\hline Sig & $=$ & 0,000 & & & & & \\
\hline
\end{tabular}

Table 4

The Result of Tenure Regression Model

\begin{tabular}{|c|c|c|c|c|c|c|}
\hline \multirow[b]{2}{*}{ Model 3} & & \multicolumn{2}{|c|}{$\begin{array}{l}\text { Unstandardized } \\
\text { Coefficients }\end{array}$} & \multirow{2}{*}{$\begin{array}{c}\text { Standardized } \\
\text { Coefficients } \\
\text { Beta } \\
\end{array}$} & \multirow[b]{2}{*}{$\mathrm{T}$} & \multirow[b]{2}{*}{ Sig. } \\
\hline & & B & Std. Error & & & \\
\hline \multicolumn{2}{|c|}{ (Constant) } & $-0,895$ & 0,139 & & $-6,451$ & $0,000^{*}$ \\
\hline \multicolumn{2}{|c|}{ TENCOM } & 0,077 & 0,031 & 0,140 & 2,503 & $0,013^{*}$ \\
\hline \multicolumn{2}{|c|}{ FIRSIZ } & 0,032 & 0,005 & 0,371 & 6,436 & $0,000^{*}$ \\
\hline \multicolumn{2}{|l|}{ BOASIZ } & 0,071 & 0,028 & 0,145 & 2,513 & $0,013^{*}$ \\
\hline $\mathrm{R}$ & $=0,451$ & & & & & \\
\hline $\mathrm{R}^{2}$ & $=0,203$ & & & & & \\
\hline \multicolumn{7}{|c|}{ Std. Error $=0,1551$} \\
\hline Fhitung & $=21,541$ & & & & & \\
\hline Sig & $=0,000$ & & & & & \\
\hline
\end{tabular}

*Sig at $5 \%$ level

\section{CONCLUSION}

Indonesia is one of the emerging countries. Saeed and Sameer (2017) show that presence of diverse commissioners in emerging countries are important, 
due to the prevalence of weak governance, greater concentrated ownership and institutional instability. Due to evidence from previous research, we get the effect of board diversity on dividend payouts. Our paper focuses on family listed companies in Indonesia. The results reveal that board gender diversity on board of commissioners is positively significant on dividend payouts ratio. Gender diverse board have better monitoring than non-gender diverse board, because they have some thinking and active oversight in evaluating management judgments (Chen et al., 2014). Female commissioners are suggested to be good monitors to protect the shareholders right. In addition, a right composition for gender and tenure on board of commissioners will enhance ability of board of commissioners to audit the financial statements on family firms.

The nationality diversity on board of commissioners indicates an insignificant relationship with dividend payout ratio. In Indonesia, we rarely found a foreign commissioner sit on the board of family firms in Indonesia. This study is limited by sample, so we recommend that future study to put more number of observations because small observations bring to unbiased result on the effect board nationality diversity on dividend payout ratio.

Thirdly, board tenure diversity is positively related to dividend payouts. Long tenure makes the board becoming mature in decision making process. With experiences, they are better to take decision in the firm (Liew et al., 2011). Moreover, new commissioners will bring the fresh ideas and critical thinking for management. Critical thinking for management will also increase the effectiveness of monitoring on financial statements (Liu \& Sun, 2005). Therefore, the company needs to have a right composition for the tenure of board of commissioners, because commissioners tenure is one of the commissioners qualities (Vafeas, 2003).

\section{REFERENCES}

Adams, R. B., \& Ferreira, D. (2009). Women in the boardroom and their impact of governance and performance. Journal of Financial Economics, 94(2), 291309.

Adjaoud, F., \& Ben-Amar, W. (2010). Corporate governance and dividend policy: Shareholders' protection or expropriation? Journal of Business Finance and Accounting, 35(7), 648-667

Ararat, M., Aksu, M., \& Cetin, A.T. (2010). Impact of board diversity on boards monitoring intensity and firm performance: evidence from the Istanbul Stock Exchange.

Bathala, C. T., \& Rao, R. P. (1995). The determinants of board composition: An agency theory perspective. Managerial and Decision Economics, 16(1), 5969.

Bebchuk, L. A. \& J. M. Fried, (2003). Executive Compensation as an Agency Problem. Journal of Economic Perspectives, 17,71-92. 
Ben-Nasr, H. (2015). Government ownership and dividend policy: Evidence from newly privatized firms. Journal of Business Finance\&Accounting, 42(5),665-704.

Bloom, N. and Van Reenen, J. (2006). Measuring and Explaining Management Practices Across Firms and Countries. CEP Discussion Paper No 716. Centre for Economic Performance London School of Economics and Political Science, London. Boston Consulting Group Report (2016).

Boumosleh, A., \& Cline, B. N. (2015). Outside director stock options and dividend policy. Journal of Financial Services Research, 47(3), 381-410.

Buchanan,B.(1974),'BuildingOrganizationalCommitment:TheSocialization of Managers in Work Organizations', Administrative Science Quarterly, Vol. 19 , pp. 533-46.

Byoun, S. (2016). Does corporate board diversity affect corporate payout policy. AsiaPacificJournal of Financial Studies, 45(1), 48-101.

Carney, M. (1998). 'A management capacity constraint? Barriers to the development of the Chinese family business'. Asia Pacific Journal of Management, 15, 1-25.

Carney,M.andGedajlovic,E.(2002).'Thecouplingofownershipandcontroland theal locationoffinancial resources: evidence from Hong Kong'. Journal of Management Studies, 39, 123-46.

Carter, D.A, D'souza, F., \&Simkins, B.J. (2008). The diversity of corporate board committees and financial performance.

Chen, G., Crossland, C., \& Huang, S. (2014). Female board representation and corporate acquisition intensity. Strategic Management Journal, 37(2), 303313.

Chen, M.-J. (2001). Inside Chinese Business. Boston, MA: Harvard Business School Press.

Choi, J.J., Parl, S.W., \&Yoo, S.S. (2007). The value of outside directors: evidence from corporate governance reform in Korea. Journal of financial and Quantitative Analysis, 42(4), 941-962. Claessens

Claessens, S. (2006). Corporate Governance and Development. The World Bank Research Observer, 21(1), pp. 91-122.

Claessens, S., Djankov, S. and Lang, L. (2000). 'The separation of ownership and control in East Asian corporations'. Journal of Financial Economics, 58,81112.

Denis, D.K. \&McConnel, J.J. (2003). International corporate governance. Journal of Financial and Quantitative Analysis 38(1), 1-36.

Dharwadkar, R., George, G. and Brandes, P. (2000). 'Privatization in emerging economies: an agency theory perspective'. Academy of Management Review, 25, 650-69.

Faccio, M., Lang, L. H. P., \& Young, L. (2001). Dividends and expropriation. American Economic Review, 91(1), 54-78.

Firth, M., Gao, J., Shen, J., \& Zhang, Y. (2016). Institutional stock ownership and firms' cash dividend policies: Evidence from China. Journal of Banking \& Finance, 65, 91-107. 
Fondas, N. \&Sassalos, S. (2000). A different voice in the boardroom: How the presence of women directors affects board influence over management. Global Focus, 12, 13-22.

Global Family Business Index, 2015.

Hamzah, A. H., \&Zulkafli, A. H. (2014). Board diversity and corporate expropriation. Procedia-Social and Behavioral Sciences, 164, 562-568.

Jensen, M. (1986). Agency costs of free cash flow corporate finance, and takeovers. American Economic Review, 76(2), 323-329.

Jurkus, A. F., Jung, P., Woodard, C., \& Lorraine, S. (2011). Women in top management and agency costs. Journal of Business Research, 64(2), 180-186.

La Porta, R., Lopez-de-Silanes, F. and Shleifer, A. (1999). 'Corporate ownership around the world'. Journal of Finance, 54, 471-517.

La Porta, R., Lopez-de-Silanes, F., Shleifer, A., \&Vishny, R. W. (2000). Investor protection and corporate governance. Journal of Financial Economics, 58(12), 3-27.

Law of The Republic Indonesia Number 40 of 2007 concerning Limited Liability Companies

Liew, C.Y., Samad, M., Munir, S., \&Alfan, E. (2011). Electronic copy available at: http:/ / ssrn.com/abstract $=1874592$

Liu, G., \& Sun, J. (2010). Director tenure and independent audit committee effectiveness. International Research Journal of Finance and Economics, 51, 176- 189.

Liu, Y., Ahlstrom, D. and Yeh, K. S. (2006). 'The separation of ownership and management in Taiwan's public companies: an empirical study'. International Business Review, 15,415-35

Megginson, W. L. (1997). Corporate finance theory. Addison-Wesley.

Morck, R., Wolfenzon, D. and Yeung, B. (2005). 'Corporate governance, economic entrenchment, and growth'. Journal of Economic Literature, 63, 655-720.

National Association of Corporate Directors (1996), Report of the NACD Blue Ribbon Commission on Director Professionalism (NACD, Washington DC)

Oxelheim, L., \&Randoy, T. (2002). The impact of foreign board membership on firm value. Journal of banking and Finance, 2, 2369-2392

Peng,M. W. (2003). 'Institutional transitions and strategic choices'. Academy of Management Review, 28, 275-96.

Peng, M. W. (2004). 'Outside directors and firm performance during institutional transitions'. Strategic Management Journal, 25, 453-71.

Peng, M. W. and Heath, P. (1996). 'The growth of the firm in planned economies in transition: institutions, organizations, and strategic choice'. Academy of Management Review, 21, 492-528.

Pucheta-Martinez, M. C., \& Bel-Oms, I. (2016). The board of directors and dividend policy: The effect of gender diversity. Industrial and Corporate Change, 25(3), 523-547.

Ruigrok, W., Peck, S., \&Tacheva, S. (2007). Nationality and gender diversity on Swiss corporate boards. Corporate Governance, vol 15. No 4, 546- 557. 
Shleifer, A. and Vishny, R. (1997). 'A survey of corporate governance'. Journal of Finance, 52, 737-83

Sing, N.K., Ling, V.M., Seng, E.Y. \& Ling, E.L.A. (2008). Relationship Between Large Shareholders, Board Governance Structure and Performance of Malaysian Listed Firm. Proceeding of MFA Conference 2008.

Saeed, A., \& Sameer, M. (2017). Impact of board gender diversity on dividend payments: Evidence from some emerging economies. International Business Review, 26(6), 1100-1113.

Schulze, W. S., Lubatkin, M. H., Dino, R. and Buchholtz, A. K. (2001). 'Agency relationships in family firms: theory and evidence'. Organization Science, 12, 99-116.

Van Pelt, T. (2013). The effect of board characteristics on dividend policy. Unpublished working paper, . The Netherlands: Tilburg School of Economics and Management, Department of Finance, Tilburg University, 162 [Unpublished].

Vance, S. (1983), Corporate Leadership: Boards, Directors, and Strategy.McGraw Hill, New York.

Vafeas, N. (2003). Length of board tenure and outside director independence. Journal of Business Finance and accounting,

Yeung, H. (2006). 'Change and continuity in Southeast Asian Chinese business'. Asia Pacific Journal of Management, 23, 229-54.30(7), 1043-1064.

Young, M. N., Ahlstrom, D. and Bruton, G. D. (2004). 'The globalization of corporate governance in East Asia: the transnational solution'. Management International Review, 44, Special Issue, 31-50.

Young, M. N., Peng, M. W., Ahlstrom, D., Bruton, G. D., \& Jiang, Y. (2008). Corporate governance in emerging economies: A review of the principalprincipal perspective. Journal of management studies, 45(1), 196-220. 